\title{
Strategies to Increase Political Participation of Samin Kudus Community in 2019 General Election
}

\author{
Eta Yuni Lestari ${ }^{1}$, Erisandi Ardhitama ${ }^{2}$, Sunarto $^{3}$ \\ \{etayuni@mail.unnes.ac.id ${ }^{1}$ \} \\ Universitas Negeri Semarang, Indonesia ${ }^{1}$ \\ Universitas Negeri Semarang, Indonesia ${ }^{2}$ \\ Universitas Negeri Semarang, Indonesia ${ }^{3}$
}

\begin{abstract}
Samin Community or Sedulur Sikep Community in Kudus Regency has a unique political participation because of the fact that political mobilization is still driven by the elder/leader of Samin Community itself. In spite of the fact that they are in one district and share the same Sedulur Sikep as their principle, nevertheless the position of leader in each village will determine political participation, moreover in using their right to vote. Samin community is a society that still upholds values, teachings, customs, languages, traditions that distinguish it from other communities. In this research, the authors want to analyse strategies to increase political participation of Samin community in Kudus Regency in the 2019 general election. The research method used in this research is qualitative research with in-depth interviews. The results of the study show that the role of the Samin figure is still compelling, the strategy undertaken by the Samin figure to encourage his citizens to use their right to vote is by using command system. Command from the leader of Samin community to his citizens is carried out in gethok tular. The command carried out is believed to be an effort to maintain pirukunan (harmony between Samin Community). In spite of the fact that the strategy of Kudus Regency Election Commission (KPUD Kudus Regency) is to form democratic volunteers to engage in community-based activities, one of which is a community base with special needs, including the indigenous people of Samin community.
\end{abstract}

Keywords: Samin Community, General Election, Strategies, Political Participation.

\section{Introduction}

Post-1998 democratization has reformed the political system in Indonesia. The new political system requires broad and open political participation. Citizens have the same opportunity to participate in elections. Both as voters and elections contestant. Demands for citizen participation in the development process, the community is no longer as an object but as a subject involved in it. Political participation makes people aware of the importance of the community capacity to increase their independence and ability to possess resources, thus people's initiative and participation as the core of development sources [1]. Included in political activities, people's participation will determine who has the right to hold the power for the next five years which will certainly have an influence on the fate of the nation and state.

Political participation can be interpreted as the activities of citizens who act as individuals to influence government decision making or policy [2]. From the democratization of postreform which is transparent, it appears that not all citizens can participate in the context of using 
their voting rights. There are several things related to whether or not the citizens want to participate in political activities; firstly, socio-economic status, secondly the situation, political affiliation of parents, organizational experience, political awareness, trust in government, incentives for participation through mass media socialization and formal discussions [3].

One of interesting case to learn in the context of citizen participation in using their voting rights in the election is the case in Samin community. This case is interesting to study for the reason that Samin Community is closely related to the local culture. If for the general public the use of the voting rights in a general election is a democratic party which must not be missed, containing obligations as well as rights guaranteed by law, Samin community has its own views regarding the use or not use of the voting rights in elections. This is due to the fact that Samin community has its own philosophies and beliefs which are held firm and consistent until now. Samin community, moreover Samin Kudus, has the principle of Samin as a belief in life, the basic principles of principles (orders), and the basic principles of prohibition (restriction) for its adherents. Samin community also has six basic principles in ethics, basic restrictions in interactions, basic teachings in principled, and do not embrace the religion authorized by the government, but rather have their own beliefs and religion which they called Adam's religion [4]. Another distinctive feature of Samin Community is that they opposed colonialism which in the past was a form of resistance against the colonizers, specifically the Netherlands, but anticolonialism continued to the present and shifted to being anti-government. Anti-government is shown by the teachings of should not educate children with formal education, not registering marriages in the civil registry, not paying taxes, and not using voting rights in general elections.

In spite of the fact that 2019 became a political year for the Indonesians, which was marked by the uproar news about candidate pairs, political parties, Quick Count, efforts to win the election contestants, which always became a public talk; nonetheless Samin Community remained calm and not too carried away by the current and political atmosphere. This is due to their teachings about restrictions in government activities. Research on Samin Community has often been carried out including highlighting cultural, religious, social, linguistic, educational accessibility, and Samin women. While research about Samin Community political participation, moreover in general election activities have not been found. For example, studies on domestication of Samin women, where Samin women in Klopo Duwur Blora are still placed as sub-ordinate for men, so that the role of Samin women is still limited to domestic activities or known as "masak, manak, macak" or "wells, kitchen, bed" [5]. In accordance with the study of the political participation of Samin Kudus community, Samin Community in responding to government policies can be outlined into three responses, such as; rejecting, actively accepting Pancasila subjects, active but refusing to accept Pancasila subjects in light of the fact that they already have their own beliefs and religions, that is the religion of Adam [4]. Another study shows the existence of local wisdom values in Samin Kudus community which consists of religious adherents of the Adam Religion, in harmony with both Samin Community and outside Samin Community, fair because it maintains a balance of human relations with God, with fellow humans, and with the environment [6]. By observing these matters it is deemed necessary to study political participation of Samin Kudus Community.

In order to conclude the discussion in this paper, the research question asked is what is the socio-cultural strategy that needs to be conceived and carried out to increase political participation of Samin Community in the 2019 elections? This believes important to study due to the fact that Samin community as part of Indonesia citizens also has the voting rights in general elections. While the teachings of Samin Community still oppose government programs as a form of rejection of colonialism. 


\section{Methods}

This research uses qualitative approach. This approach seeks to understand and analyze Strategies for Increasing Political Participation of Samin Kudus Community in the 2019 General Elections and trying to discover new things based on the results of the data in the field. Field data referred to in this study is in the form of understanding and interpretation of the research object, that is Samin Community from the results of direct interaction, the reality life of Samin Community, and it is related to the theory or the results of previous research. Data collection was carried out using participatory observation techniques such as; by seeing, observing directly Samin Community in everyday life during the data collection process. Other data collection methods are interviews, conducted with informants from Samin community elders, from two different locations and figures, and with natives outside Samin Community, as well as the Kudus Regency Election Commission. Data analysis uses interactive models, with stages of data collection, data reduction, data display, and conclusions [7]. Use of interactive models in data analysis to find Strategies to Increase Political Participation of Samin Kudus Community in the 2019 General Elections. Data collection is done by summarizing, choosing the main and crucial things related to Samin Community, including the values of local wisdom, social interaction, political participation, strategies to increase political participation through interviews. Data reduction is done by sorting out the appropriate data, which is capable of providing research findings. Data display is carried out by compiling information data that provides possible conclusions of research findings. Drawing conclusions by drafting an answer from the research results and data obtained during the study.

\section{Result and Discussion}

\subsection{Understand Samin Community}

Samin community in Central Java is found in several areas, they can be found in Blora Regency, Pati Regency, and Kudus Regency. In general, Samin Community in Blora, Kudus and Pati have similar characteristics. Members of Samin community are also known as Wong Samin, Wong Sikep, or Wong Adam. Named Wong Samin due to the fact that this community is a follower of a figure whose name is Samin Surosentiko. Called Wong Sikep because this community emerged from marriage or sikepan (Javanese language). Wong Adam was called because the community claimed to be followers of Adam's Religion [5]. The designation of Wong Samin is often understood negatively by wider communities who do not know Samin community. That is due to the fact that the name Samin is often associated with attitudes or ways of life that are old-fashioned, stupid, rebellious, uncooperative, unwilling to pay taxes, like to oppose, and often do passive movements [8].

Samin Community (Sedulur Sikep) emerged during Netherlands settlement of Java. The term "Samin" is a term for people who hold the teachings of Ki Samin Surosentiko. Because the term "Samin" is often negatively connoted, Samin community embeds itself as Sedulur Sikep. From political aspect, Samin Community is known as a dissident, so its existence has become an endeavour by the Netherlands authorities. The activities carried out by Samin community against Netherlands authorities were (1) opposing occupation with a typical movement that was not willing to pay taxes, (2) not wanting to participate in mutual cooperation activities (fall of the mountains) because the road built with mutual cooperation would only facilitate 
transportation of The Netherlands, (3) invites the community to speak honestly to fool the invaders with kiratabasa [9].

Teachings that are believed by Samin community and become indigenous knowledge Sedulur Sikep/Samin are divided into two, there are (1) teachings that must be abandoned and (2) teachings that must be implemented. Similar was expressed by Rosyid, that Samin's teachings were made life beliefs in the form of basic teachings (orders) in the form of ethics, basic restrictions on interacting, principles of character, and religious [9]. Prohibition teachings in the teachings of Samin Community are drengki (slander), srei (greedy), panasten (easily offended), dawen (accusing without evidence), kemeren (envy), nyinyo marang sepodo (behaving badly towards others) bedok (accusing), colong (stealing), njumput (taking even in small amounts), pethil (picking or taking something that is still united with the main part), and nemu barang liyan (finding other people's belongings). The teachings that must be carried out are reti nggone dewe (understanding his own belongings); lugu (say something as is or be honest in speaking and acting); mligi means the community jejeg (obedient to the teachings) and rukun.

Distinctive features of Samin community include believing in a religion called Adam's Religion, earning a living as a farmer, not knowing formal schools, marriage not registered in government administration, not having a Family Card, and rejecting everything related to Netherlands lifestyle (action) such as fashion style. Samin people do not want to wear trousers but rather pants right below the knee, not wearing cap but wearing udheng, wearing shirt, wearing sarong, wearing a typical black dress at an official event, using caping/hat when working in the fields, and not allowed to have more than one wife [4].

\subsection{Political Participation of Samin Community In 2019 Election}

Political participation of Samin community in the general election cannot be separated from the role of Samin community elders. From the results of research that has been conducted since 2018, the role of community elders in each region turned out to have an impact on the decision to vote in elections. Participation is a determination of attitude and self-involvement in each individual in a group's situation and condition, hence in the end it encourages the individual to play a role in achieving the goals in a group, and to take part in joint accountability [10].

Political participation in indigenous communities has unique characteristics. This is due to the intersection between diverse local cultures and politics. The uniqueness also occurs in light of the fact that there is a different logic between social systems in the modern and traditional periods. In modern times, power relations are based on the power of capital and networks. Whereas in the traditional feudal-based system. Thus, in traditional times, the character of power was obtained by being passed on, not by election. Actors who dominated the traditional political system were nobles and aristocrats. Both are different. Nobility is obtained ascriptive through lineage, while aristocracy is obtained through education, intimacy to the king or prince, and experience working in the governmental institutions of the palace [11][12][13][14][15][16]. As well as political character in Samin Community which is also interesting. As in Samin Community in Undaan Subdistrict, moreover in Kaliyoso Village and Larik Rejo Village. Samin community has different characteristics, this is due to the difference in the leader/elder of Samin Community. There are at least 2 major explanations regarding this matter.

First, Samin Community, led by Mr Santoso, showed a low level of trust in the government, thus, they tended not to use their right to vote in the elections. Another reason they did not use their right to vote was that according to Samin's philosophy all people were brothers, including all contestants in the general election. Therefore it is not appropriate to choose only one of several contestants. It is not fair if someone has to choose one pair of candidates for 
president/vice president or a legislative candidate, while for all of them are brothers. Thus in the context of the philosophies of Samin that they profess, they prefer not to come to the polling station to use their voting rights rather than having to choose one of their fellow brothers.

Both of Samin community under the leadership of Mbah Wargono, their level of political participation was included in active political participation. Samin community under the leadership of Mbah Wargono used the right to vote as a form of support for leaders in the government. From the results of interviews with Mbah Wargono, many government officials in Kudus Regency visited his house. Among the officials were Kudus Regent (Mustofa) and Central Java Governor Candidate in 2008. Rosyid's research results revealed the same thing, that in the election of Kudus Regent in the 2008-2013 period, the majority of Samin Kudus community chose Mustofa Wardoyo who was paired with Budiyono. In the end the election was won by the couple Mustofa-Budiyono [9]. The community of Samin Kudus was compact in supporting the couple Mustofa-Budiyono because Mustofa came to the residence of Mbah Wargono and the Head of Karangrowo Village. Samin Kudus community together followed Mbah Wargono's suggestion to choose Mustofa as the regent of Kudus at that time.

Natives outside Samin community stated that among the elders of Samin community there were those who still firmly adhered to the teachings of Samin and some who were not compelling in holding the teachings of Samin. In terms of participation in education, for example, Samin community under the leadership of Mr. Santoso tended to open up. They suggest their children to attend formal school even in spite of the fact that only until they can read and write (elementary school level). Furthermore, their livelihoods are no longer only as farmers, but also some of them work outside Java as gold miners. Whereas in Samin community under the leadership of Mbah Wargono still upholds the teachings of Samin by not allowing children of Samin community to get formal education at school. They believe that parents are the best teachers for their children. They do not feel the need to be able to read and write because with education from parents can already read what is good and what is bad in life. Their livelihoods are only as farmers, because in their view becoming farmers is an expression of gratitude to the Almighty who has provided life (food) from the results of their fields, and it is appropriate to preserve the environment and the earth as a source of their living.

Other than Samin figure factor, political participation of Samin community is also driven by factors that come from within themselves. The encouragement arises because the person concerned is visited by general election contestants such as candidates for district ruler/vice or candidates in the electoral district. The unique thing about Samin community is that it is innocent/honest, and with the innocence that if visited by more than one candidate, they actually do not use their voting rights, nevertheless only come to the polling station to meet the invitation of the committee. They did this for the reason that they wanted to be fair and did not want to hurt one of the candidates in question. When given money (money politics) more than one candidate, they will only receive from one of the candidates who gave it the first time. They did it because they did not want to be greedy, an attitude which was taboo according to Samin's teachings. Another factor is a factor derived from a life partner (husband) for Samin women. Samin women make their choices more based on the husband's direction because they feel that the wife is under the responsibility of the husband.

\subsection{Strategies to Increase Political Participation of Samin Community}

In order to find a strategy to increase political participation of Samin Community, the authors conducted an interview with Alan who was a member of Kudus District Election Commission and also Mr. Santoso and Mbah Wargono who were leaders of Samin Community. 
The strategy to increase political participation of Samin Community is carried out with the aim of fulfilling the target of voting in Kudus Regency by $75 \%$ for all levels of society in Kudus Regency. The strategy carried out by the Kudus Regency KPU in particular socialization division, they formed democratic volunteers consisting of 55 people who were divided into 10 groups to go into the community. Democratic volunteers are relegated to youth, novice voters, families, netizens, people with disabilities, marginalized, housewives, prisoners, and people with special needs including indigenous peoples. Samin community is included in the special needs base. The socialization technique that was carried out was to go directly to the leaders / leaders of Samin to provide an understanding of the use of voting rights in the 2019 general election. From the results of interviews with the Commission obtained information that the political participation of Samin community in the 2019 elections was great.

According to the interviews with Mbah Wargono and Mr. Santoso, the strategy taken by Samin figure to encourage his citizens to use their right to vote is to use the command system. The command of Samin Community leader to its citizens is carried out in gethok tular. The command carried out is believed to be an effort to maintain harmony (harmony between Samin community). Now Samin Kudus community is more responsive and accommodating to government policies. The role of Samin community figure in determining political participation of its citizens is still huge. Another role of Samin figure is to encourage his citizens to nyengkuyung the candidate who has entrusted a name (candidate) to the figure. However, there are also those who do not use their right to vote for reasons, first, they still hold to the position that all candidates are sedulur (brothers), and it is not fair if they must choose one of the candidates. Second, distrust of candidates in light of the fact that the candidates are said to be representatives of the people nevertheless have never come to their homes and interact directly with them. Third, the election activities are not crucial and do not affect their lives.

\section{Conclusion}

From the description above it can be concluded that Samin community has a different perspective from the community in general in responding to various problems in personal, social, and social life; including in responding to government programs. Furthermore, Samin community still shows solid paternalism or shows a solid example by making Samin community leader their reference figure. Therefore, their political participation was greatly influenced by the leader of Samin community. In line with that the strategy undertaken by the Election Commission to increase political participation of Samin community in Kudus Regency is through the dissemination of socialization in the form of a team of democratic volunteers formed by the Election Commission. The volunteer team is assigned to give socialization to the community through Samin community leaders that they are used to meet. In spite of the fact that the strategy carried out by the figure of Samin Kudus to encourage political participation of its citizens is to use "command" system. Commands from Samin community leaders are transmitted from one citizen to another in Samin community.

\section{References}

[1] E. Prasojo and D. Prof, "People and Society Empowerment: Perspektif Membangun Partisipasi Publik," J. Ilm. Adm. Publik, vol. 4, no. 2, pp. 10-24, 2004. 
[2] M. M. Fenyapwain, "Pengaruh Iklan Politik Dalam Pemilukada Minahasa Terhadap Partisipasi Pemilih Pemula di Desa Tounelet Kecamatan Kakas," J. Acta Diurna, vol. 2, no. 1, 2013.

[3] D. Hendrik, "Variabel-variabel yang Mempengaruhi Rendahnnya Partisipasi Politik Masyarakat dalam Pilkada Walikota dan Wakil Walikota Padang Tahun 2008," J. Demokr., vol. 9, no. 2, 2010.

[4] M. Rosyid, "Partisipasi Politik Komunitas Samin Bidang Pendidikan,” Edukasia Islam., vol. 7, no. 2, 2009.

[5] M. Mukodi and A. Burhanuddin, "Domestifikasi Perempuan Samin dalam Khasanah Masyarakat Islam Modern," Al-Tahrir J. Islam. Thought, vol. 15, no. 2, pp. 411-430, 2015.

[6] E. Y. Lestari, "Nilai-nilai Kearifan Lokal Pada Masyarakat Sedulur Sikep Kudus," in Seminar Nasional PKn UNNES, 2018, vol. 2, no. 1, pp. 192-198.

[7] I. Gunawan, "Metode Penelitian Kualitatif: Teori dan Praktik. Edisi kesatu, Cetakan keempat," PT. Bumi Aksara. Jakarta, 2016.

[8] I. P. Lestari, "Interaksi Sosial Komunitas Samin dengan Masyarakat Sekitar," Komunitas Int. J. Indones. Soc. Cult., vol. 5, no. 1, 2013.

[9] M. Rosyid, "Perempuan Samin dalam Tantangan Politik lokal di Kudus Jawa Tengah," PALASTREN J. Stud. Gend., vol. 7, no. 2, pp. 397-418, 2016.

[10] A. Suharyanto, "Partisipasi Politik Masyarakat Tionghoa dalam Pemilihan Kepala Daerah," JPPUMA J. Ilmu Pemerintah. dan Sos. Polit. Univ. Medan Area, vol. 2, no. 2, pp. 151-160, 2014.

[11] C. Geertz, A. Mahasin, and B. Rasuanto, Abangan, santri, priyayi: dalam masyarakat Jawa, no. 4. Pustaka Jaya, 1983.

[12] Koentjaraningrat, Kebudayaan, mentalitet, dan pembangunan: bungarampai. Gramedia, 1974.

[13] N. Mulder, Mistisisme Jawa. LKIS PELANGI AKSARA, 2001.

[14] A. A. Dwipayana, Bangsawan dan kuasa: kembalinya para ningrat di dua kota. Institute for Research and Empowerment, 2004.

[15] S. Selo, "Perubahan Sosial di Yogyakarta," Jakarta: Penerbit Komunitas Bambu, 2009.

[16] E. Arditama, "Mereformasi Birokrasi dari Perspektif Sosio-Kultural: Inspirasi dari Kota Yogyakarta,” J. Ilmu Sos. Dan Ilmu Polit., vol. 17, no. 1, pp. 85-100, 2013. 